\title{
Proposing Waqf New Form (WNF) In Waqf Land Registration System In Malaysia
}

\author{
Noor Azimah Ghazali a, Ibrahim Sipana*, Ahmad Che Yaacob \\ ${ }^{a}$ Center Real Estate Studies, Faculty of Built Environment and Surveying, Universiti Teknologi Malaysia, 81310 \\ Johor Bahru, Johor \\ ${ }^{b}$ Academy of Islamic Civilation, Faculty of Social Sciences and Humanities, Universiti Teknologi Malaysia, 81310 \\ Johor Babru, Johor \\ *Corresponding author: ibrabimsipan@utm.my
}

Article history

Received: 2021-03-17 Received in revised form: 2021-04-29 Accepted: 2021-04-30 Published online: 2021-10-30

\begin{abstract}
This paper highlights and discusses the various forms and procedures involved in the registration process of waqf land and suggest the Waqf New Form (WNF) as a solution to the issues that arise in the registration of waqf land in Malaysia. The study sought to answer the following two research questions: What issues arise in the method of waqf land registration in Malaysia? In what ways can such issues be resolved? Design/methodology/approach: This study employed a qualitative research approach and used content analysis to analyse data. Data were collected through semi-structured interviews with lawyers, academicians, and executive officers from the Department of Land and Mines (DLM) and the State Islamic Religious Council (SIRC), and reviewed documents were collected mainly from the Department of Waqf, Zakat and Hajj Malaysia (JAWHAR). The study found the $W \mathrm{NF}$ to be a solution to the issues that arise in waqf land registration. It was developed to address the current waqf issues such as problematic registration methods, lengthy and complicated procedures, interference in the civil court jurisdiction, and idle waqf land. The $W \mathrm{NF}$ resolved the flaws of the previous waqf land registration system in Malaysia. The $W \mathrm{NF}$ will provide solutions to the current registration system within the National Land Code, 1965 (NLC), which will secure property rights in the future.
\end{abstract}

Keywords: waqf, land, registration, legal, amendment.

\subsection{INTRODUCTION}

The land is a valuable asset for every state. Due to the high demand and land scarcity, it is crucial for land to be registered and appropriately managed. In Malaysia, land titling is crucial for all land, including waqf land, must be registered for the Land Title to ensure land indefeasible ownership as stipulated under the Malaysian Federal Law in Section 340 of the National Land Code (NLC). There are three methods to register waqf in Malaysia: Statutory Vesting, Surrender and Re-alienation and Transferred Title. Several issues arise from these methods. They can cause confuse and applicants can also face difficulties in submitting different forms for different procedures. The procedures are quite lengthy and may result in insecure transfer to the extent that heirs can revoke the waqf in the future (Ghazali \& Raji., 2019; Hamid \& Tahir, 2014; Mohammad, 2013).

This paper highlights and discusses the various forms and procedures involved in the registration process of waqf land and suggests the Waqf New Form $(W N F)$ to solve the issues that arise in the registration of waqf land in Malaysia. The study sought to answer the following two research questions: What issues arise in the method of waqf land registration in Malaysia? In what ways can such issues be resolved? 


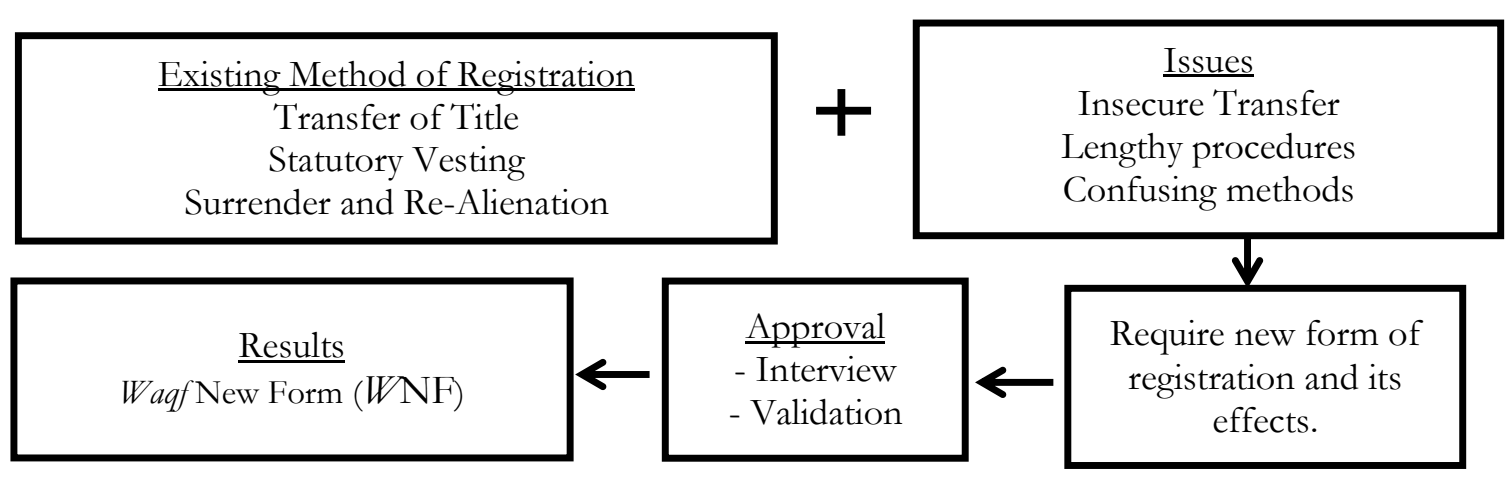

Figure 1 The process of formulating a New Form in Waqf Land Registration System in Malaysia Source: Author, (2020)

As presented in Figure 1, this paper highlights the issues in waqf land registration and suggests the $W \mathrm{NF}$ as a solution to the issues that arise in the waqf land registration system in Malaysia. Semi-structured interviews were used for empirical data collection. This method allowed the interviewer to validate the issue and the $W \mathrm{NF}$ within the waqf land registration system. During data collection, the method of waqf land registration suggested most commonly was Statutory Vesting. Therefore, the Statutory Vesting method with the $W \mathrm{NF}$ should be used in waqf land registration in Malaysia.

The Waqf land registration system in Malaysia compromises the conservation of the property. Therefore, the interview will assist in investigating the root cause of the problem. Purposive sampling was adopted to select the most appropriate and relevant respondents involved in the waqf land registration system. This paper is organised as follows: it provides a review of existing literature on the Waqf land registration system in Malaysia and describes the methodology used to collect data. The paper then presents and analyses the findings of the study. Finally, it provides a brief description of the $W \mathrm{NF}$ as a solution for the waqf land registration issues.

\subsection{LITERATURE REVIEW}

Few studies have been conducted on waqf properties. Some scholars have focused on financial issues and funds generation (Khan et al., 2020; Sukmana, 2020; Zauro et al., 2020), and others on the demographic groups experiencing economic problems that can be targeted for donations by cash waqf institutions for their marketing campaigns (Hariyanto et al., 2020; Razak, 2020). Artha et al., (2020), Hossain (2019) and Tajudin et al. (2020) designed a conceptual model of Islamic microfinance and rehabilitation by using waqf funds for the slum and floating population. Zain and Sori (2020) designed a potential sustainable and responsible investment (SRI) Sukuk model and sought the opinion of subject-matter experts and industry practitioners on the model, its attractiveness to investors, and its feasibility of its implementation in Malaysia. Osman and Agyemang (2020) argued for the involvement of beneficiaries in matters that impact them.

\subsection{The Current Waqf Land Registration System}

Some scholars have also conducted fundamental theoretical research on the scope of jurisprudential flexibility in modern waqf (Abdullah, 2020). Bazzi et al. (2020) explore the religious foundations influence in politics and society. Shabbir (2018) and Tumirin et al. (2020) investigated the waqf assets and business asset's philosophy to reconstruct assets and waqf assets' definitions and concepts. 
Some studies on waqf relate to technology. For example, Komalasari, (2020) studied a webbased system whose purpose was to create a complete and accurate database describing the actual conditions of the $W$ aqf cemetery land in the Karees, Cibeunying, Bojonegara, and Tegallega areas. Asni et al. (2020) studied the istibdal waqf concept using a geographical information system (GIS) to benefit socio-economics and Muslim cemetery waqf management to establish whether it fulfils the criteria set for istibdal. Iman et al. (2020) focused on an online-based waqf management system in Indonesia as a new model for the management of waqf administration.

Few studies focus on wagf land registration. These include Ghazali \& Sipan. (2019) who highlighted nine issues from the organisation and the donors involved in the waqf land registration process and suggested nine improvement proposals by the State Islamic Religious Council (SIRC) Johor. Osman et al. (2018) examined the procedure in the registration of waqf land from a legal perspective regarding provisions in the NLC of 1965 and the state law under the Administration of the Religion of Islam (State of Penang) Enactment 2004. Abu Talib et al. (2020) studied the effects of institutional pressures that shape the intention to adopt waqf accounting and reporting. Ismail et al. (2015) concluded that SIRCs in all states must be professionally restructured to improve the administration, management, and development of waqf land in Malaysia. Akhtar (2013) showed that a waqf created in another country could be regulated as a charitable institution whereby the settler disposes of his property for charitable purposes.

These studies have highlighted waqf land registration and have proposed some suggestions, such as improving reporting and providing training services. Some of the studies suggest giving a power of attorney to non-governmental organisations or private associations to act as trustees to register the land as waqf. While this seems to be a great solution, it does not fully cover waqf properties' security because the registration method is lengthy and revocable. Therefore, this study sought to highlight the issues waqf land registration and suggested the $W \mathrm{NF}$ for the waqf land registration system in Malaysia.

\subsection{Waqf Land Registration Under The Malaysia Legal System}

To make waqf indefeasible, binding, valid, and recognised under the Malaysian legal system, the waqf must be declared at SIRC in front of a waqf officer. The provision of the NLC is applies to the Torrens system, which holds that the principle of registration is everything. Therefore, waqf needs to be registered under Section 215 of the NLC (Transfer of Title, form 14A), Section 195 of the NLC (State Surrender and Re-alienation, form 12A and form 12B), or Section 416 of the NLC (Statutory Vesting, form 30A, and form 30B). The steps for waqf land registration include applying and preparing the Layout Plan, Ground Report, Land Reports, Admission Form and Letter, Registration and Vesting, Submitting Notices, Stamp Duties Exemption, Periodic Surveys and Gazetting Land (Ghazali et. al, 2021). The Department should approve the registration of Survey and Mapping, Land Administrator, Department of Lands and Mines, State Authority, and Local Authority (Rani \& Ghani, 2012). Finally, after approval, the certificate of the title is transferred to the SIRC. After that, the waqf land becomes indefeasible, binding, and valid under Civil Law, NLC, States Enactments, and the Court. The registration process is assisted by the Department of Lands and Mines and the Department of Survey and Mapping (Rani \& Ghani, 2012). 
Table 1 Method of Waqf Land Registration in Land Office at Malaysia Source: NLC, (1965)

\begin{tabular}{|l|l|l|}
\hline \multicolumn{1}{|c|}{$\begin{array}{c}\text { Method of Waqf Land } \\
\text { Registration. }\end{array}$} & \multicolumn{1}{c|}{ Provision of NLC } & \multicolumn{1}{c|}{ Forms } \\
\hline Transfer of Title & Section 215 & form 14A and form 14B \\
\hline State Surrender and Re-alienation & section 195 & form 12A and form 12B \\
\hline Statutory Vesting & Section 416 & form 30A and form 30B \\
\hline
\end{tabular}

Initially, it seems that the process of waqf declaration in Malaysia is compliant with Islamic law, whereby the existence of the five elements/pillars of waqf shall make the waqf valid and binding. However, under the process of waqf registration in Malaysia, several problems have been discovered. Currently, there is no specific legislation on waqf. There are many forms and procedures involved, as shown in Table 1. This diversity can confuse, and the applicants can also face difficulties submitting different forms for different procedures. Besides, each method is problematic, as described below:

i. Statutory Vesting: The endorsement on statutory vesting under Section 416C is only made on the title's certificate. The name of SIRC is only endorsed as the manager of the land. Provisions are referred to as rights in whole or partial of alienated land are vested in the transferee. Statutory vesting is not considered registered ownership. It limits the scope of ownership of SIRC by just giving rights to occupation, use, control, or management. Therefore, it does not secure the status of waqf to be indefeasible in the future, and SIRC may have problems transferring the land within the procedure of istibdal. Therefore, Muslims or the waqf land beneficiaries may lose the rights to receive compensation for land acquisition since SIRC is not the registered owner of the land (Ghazali \& Raji, 2019; Rani \& Ghani, 2012).

ii. Surrender and Re-alienation: This method requires the land to be transferred to the state and re-alienated to SIRC. However, its status is unclear under Section 195. The NLC mentions that either the land or waqf land is alienated as state reserve land (Ghazali \& Sipan, 2019; Kader et al., 2009). State reserve land causes the status of waqf land to be removed and the land can be taken at any time by the state without compensation. Besides, some of the lands are taken for public use (e.g., road and passage under the process of surrendering the land to the government without compensating the property owner (SIRC/waqif).

iii. Transferred Title: In recent times, the method of transferring the title is long and complex. It is also contradictory to the waqf property's nature because fit is transferred to SIRC without the waqf clause. It shall only be owned by Allah and cannot be transferred to anyone (Ghazali \& Sipan, 2019; Kader et al., 2009).

The methods mentioned above have many weaknesses: lack of standardised practices and detailed laws, procedures, and clear rules to declare and register the land under the SIRC and NLC.

\subsection{METHODOLOGY}

This study adopted a qualitative approach understanding the underlying reasons for the waqf issues of by obtaining expert opinions and developing ideas or hypotheses so that changes could be suggested (Crossman, 2017). This research adopted a content analysis, which included reasoning by inducting the law related to waqf land registration and deducting it to the scope of this study (Pacific, 2014). Twelve interviews were conducted to gather the expert's opinions on 
waqf land registration system in Malaysia. By content analysis in literature review and interviewing respondents, the waqf land declaration and registration system are improved by suggesting new waqf registration forms in Malaysia. Finally, the proposed new forms, and proposed method were validated by the same experts

A purposive sampling method was used to select respondents based on specific characteristics or criteria concerning the study's needs, as shown in Table 2. The sample was selected by looking at respondents' relevant characteristics of respondents and the suitability of locations (Kumar, 2019). Data were collected from four states, namely Melaka (MKE), Negeri Sembilan (NSWE), Johor (JWR), and Selangor (SWE), including the Department of Land and Mines and several experts in the relevant area. These four states were selected because their enactments were better than that of the other states in terms of waqf registration and declaration.

Table 2 List of Respondents

Source: Author, (2020)

\begin{tabular}{l|c}
\multicolumn{1}{c|}{ Respondents } & Code \\
\hline State Islamic Religious Council & S1, S2, S3, S4 \\
\hline Department of Land and Mines & D1, D2, D3, D4 \\
\hline Academia in Land Law and Waqf Regulation & E1, E2 \\
\hline Lawyers in Land Law and Waqf Regulation & E3 \\
\hline Department of Wakaf, Zakat and Hajj (JAWHAR), 2004 & E4 \\
\hline
\end{tabular}
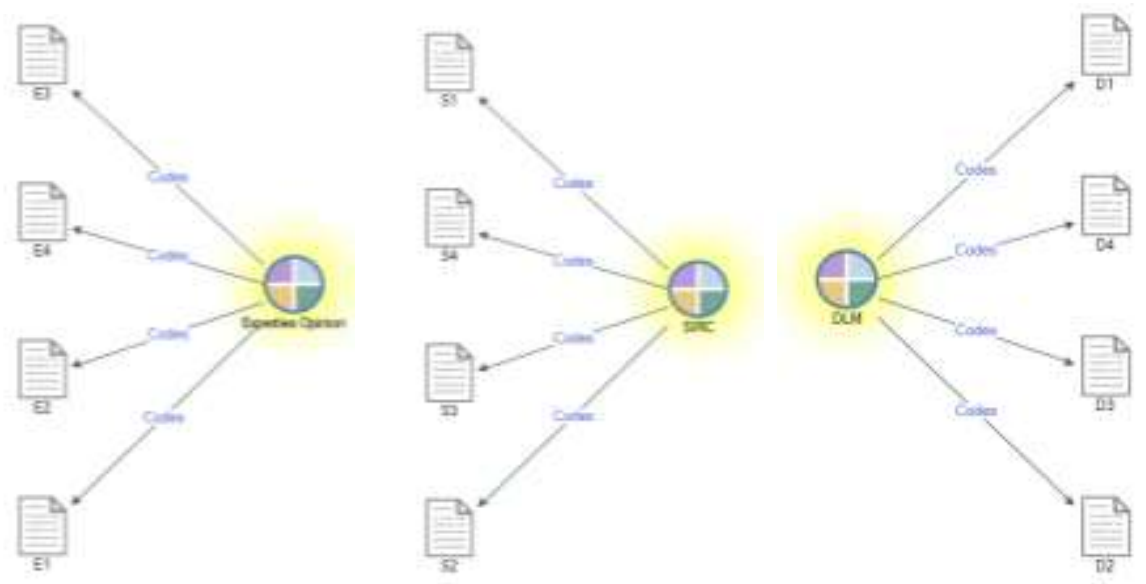

Figure 2 Group of respondents Source: Author, (2020)

All respondents requested their names to be anonymised for confidentiality. They are classified as D1, D2, D3, and D4 for the Department of Land and Mines, S1, S2, S3, and S4 for SIRC and E1, E2, E3, and E4 for Expert Opinion in the NVIVO 12 software(refer Figure 2). The interviews were transcribed, validated and coded. 


\subsection{RESULTS AND DISCUSSION}

The data were visualised in a graph and scheduled based on the experts' opinions. As Figure 3 shows, the most referenced law by the respondents is the NLC of 1965. However, the NLC does not cover any part of the waqf provision. The NLC declares in Section 4(2) the unique position of waqf lands and that nothing in the NLC provision shall affect waqf: "By Section 4(2) which states to the effect that nothing in the NLC shall affect the provisions of (e) any law for the time being relating to waqf or baitul mal."

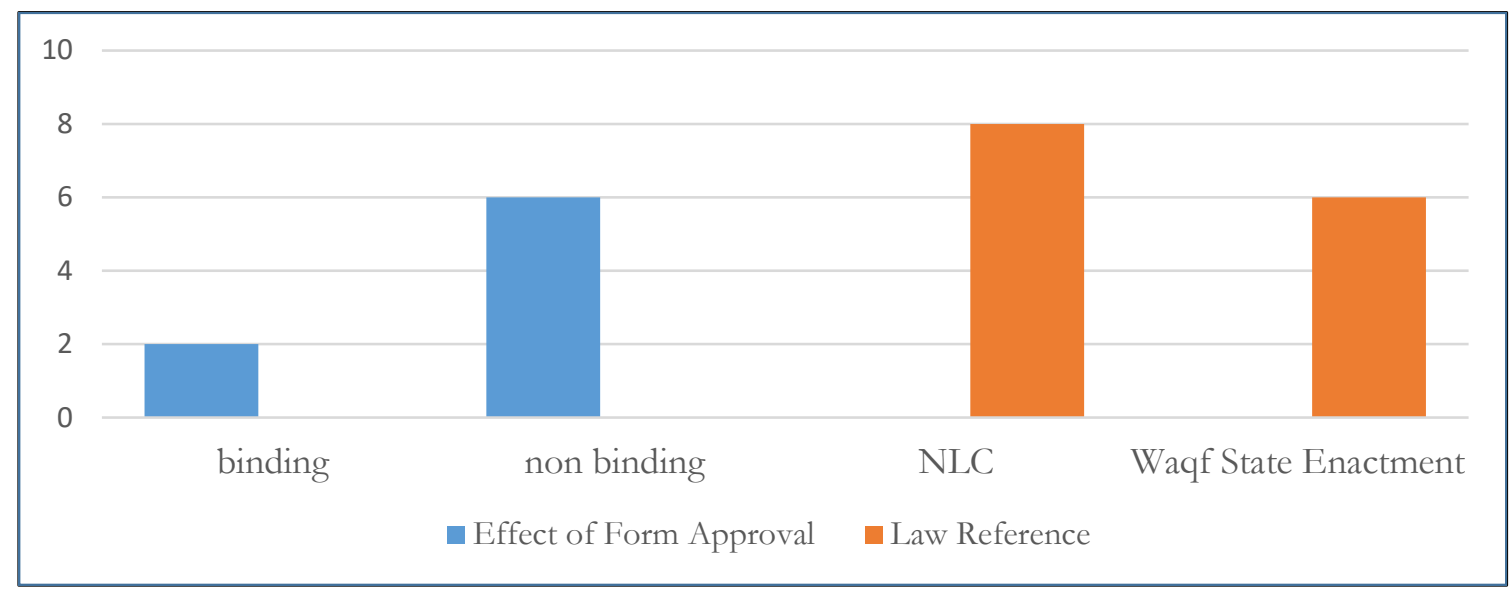

Figure 3 Effect of Decalaration In NLC Form Approval and Law Reference to Register the Land At NLC Source: DLM, SIRC and Experts, (2019)

Therefore, to improve the waqf land registration system, there is a need for waqf provision under the NLC. Besides, the NLC applies the Torrens system of land registration that emphasises that all the land, including waqf land, must be registered for the Land Title to ensure land's indefeasible ownership as stipulated under the Malaysian federal law in Section 340 of the NLC. As mentioned earlier, there are three methods of waqf land registration under the NLC of 1965, and these are: Section 215 of the NLC (Transfer Title); Section 195 of the NLC (State Surrender and Re-alienation); and Section 416 of the NLC (Statutory Vesting. Empirically).

The interviews also revealed that some forms were used for wagf land registration at the Land Office and SIRC, as shown in Table 1. Currently, waqif signature on the NLC forms and declaration at SIRC's form is not indefeasible. Therefore, the respondents suggested that the WNF should replace all the forms and should be indefeasible, as shown in Figure 4. The waqif is required to fill in the form and submit it to the Land Office as proof of donation to declare the property. The form is proof that the waqif declaration is binding and valid. Islamic law emphasises that the waqf shall be indefeasible after the waqif declaration to donate the property as waqf (Hamid \& Tahir, 2014). 
Table 3: Current method in Waqf Land Registration System Source: DLM, SIRC and Experts, (2019)

\begin{tabular}{|l|l|}
\hline \multicolumn{1}{|c|}{ Respondents } & \multicolumn{1}{c|}{ Opinion } \\
\hline S4, D4: & $\begin{array}{l}\text { The method used to register waqf land at the land office is statutory } \\
\text { vesting }\end{array}$ \\
\hline $\begin{array}{l}\text { S1, S2, S3, D1, } \\
\text { D2, D3: }\end{array}$ & The method of registration used is surrender and re-alienation \\
\hline E1, E2, E4: & $\begin{array}{l}\text { The experts have suggested the method of statutory vesting as the best } \\
\text { method to register waqf land in the Malaysian legal system. Statutory } \\
\text { vesting makes waqf land registration faster and convenient since it only } \\
\text { endorses SIRC on the title and does not involve any transfer of name on } \\
\text { the land title. }\end{array}$ \\
\hline D2: & $\begin{array}{l}\text { Statutory vesting endorsement is insufficient for SIRC because only the } \\
\text { registered name on the land title has full indefeasible ownership on the land } \\
\text { for dealing and development on the said land. }\end{array}$ \\
\hline S2: & $\begin{array}{l}\text { Surrender and re-alienation would reduce the waqf land's original size, since } \\
\text { the state would take some parts of it for road and public uses without } \\
\text { compensation. }\end{array}$ \\
\hline
\end{tabular}

Table 3 shown the respondents opinion on the method used by the stakeholder to register the land as waqf in the land office. The most common method to register waqf land is through surrender and re-alienation based on respondents' opinions. However, the respondents suggested that the best method to be used is statutory vesting. This method, which is fast and easy, only requires the endorsement stamp on the waqf property title. However, the statutory vesting on the title is insufficient because it is only an endorsement, as has been mentioned by Rani and Ghani (2012). Therefore, the SIRC process of dealing with and developing land in the future will be complicated. For this reason, it would be beneficial to apply statutory vesting with several amendments, namely recognising indefeasible rights to SIRC by changing the name on the title to SIRC.

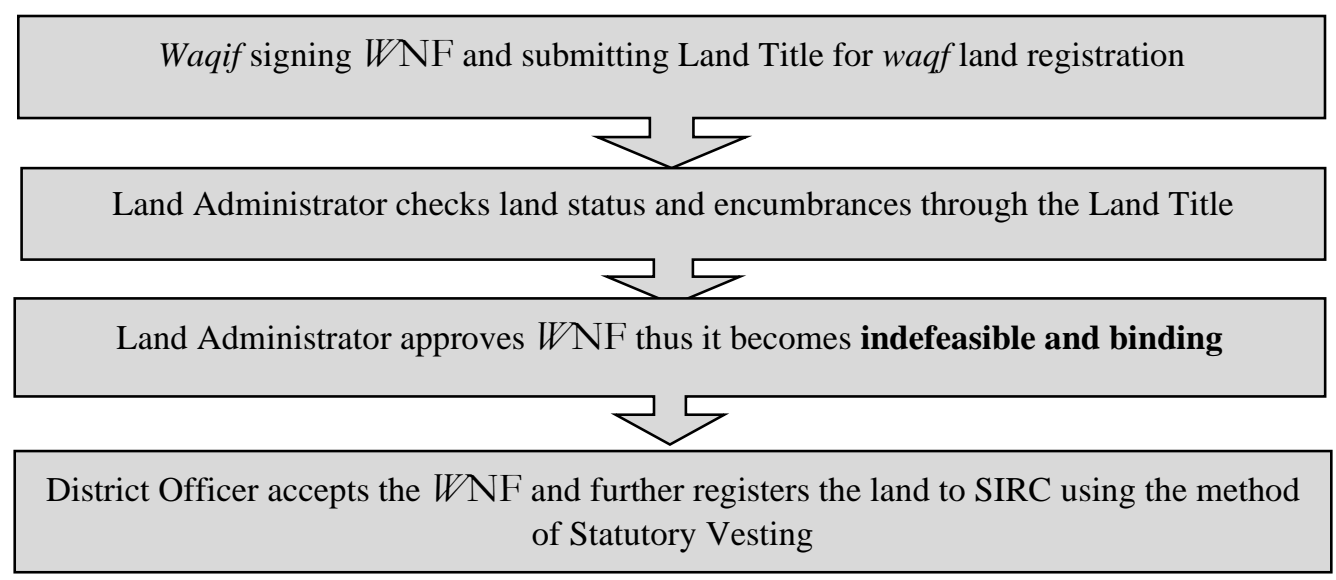

Figure 4 The Proposal of $W$ aqf New Form (WNF) in Waqf Land Registration in Malaysia Source: DLM, SIRC and Experts, (2019)

The $W N F$ is proposed to be registered using the statutory vesting method because there is no specific procedure or form in the NLC to register waqf (Mohamood, 2005; Persekutuan, 2019). The researchers suggest that the Land Administrator's approval on the WNF shall bind the waq land as indefeasible with the effect of being perpetual, inheritable, and irrevocable to donors and their heirs, SIRC, Land Office, DLM, and the Court. After the approval of the $W \mathrm{NF}$, the rest of the procedure for the application and preparation of technical progression such as the Layout Plan, 
Ground Report, Land Reports, Admission Form and Letter, Registration and Vesting, Submitting Notices, Stamp Duties Exemption, Periodic Surveys and Gazetting Land shall be carried out as usual. Overall, every step in the procedure is significant for a systematic process of land registration. However, the steps concerning technical progression can be done after the land ownership is secured as a waqf property.

\subsection{Waqf New Form (WNF)}

As mentioned earlier, the $W \mathrm{NF}$ has been promoted by the respondents and validated by the experts. Accordingly, the $W \mathrm{NF}$ is suggested to be indefeasible with the effects of being perpetual, inheritable, and irrevocable.

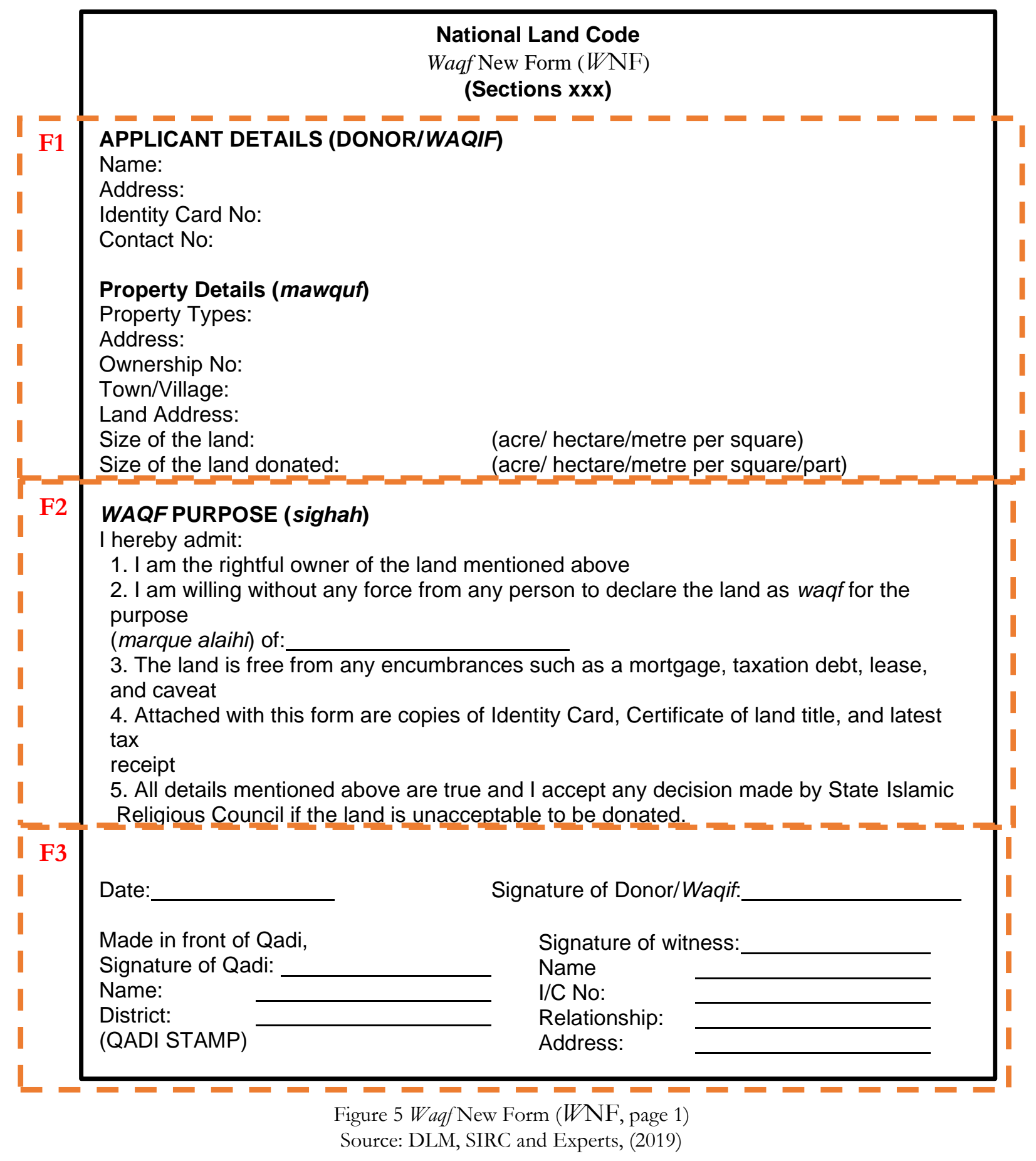




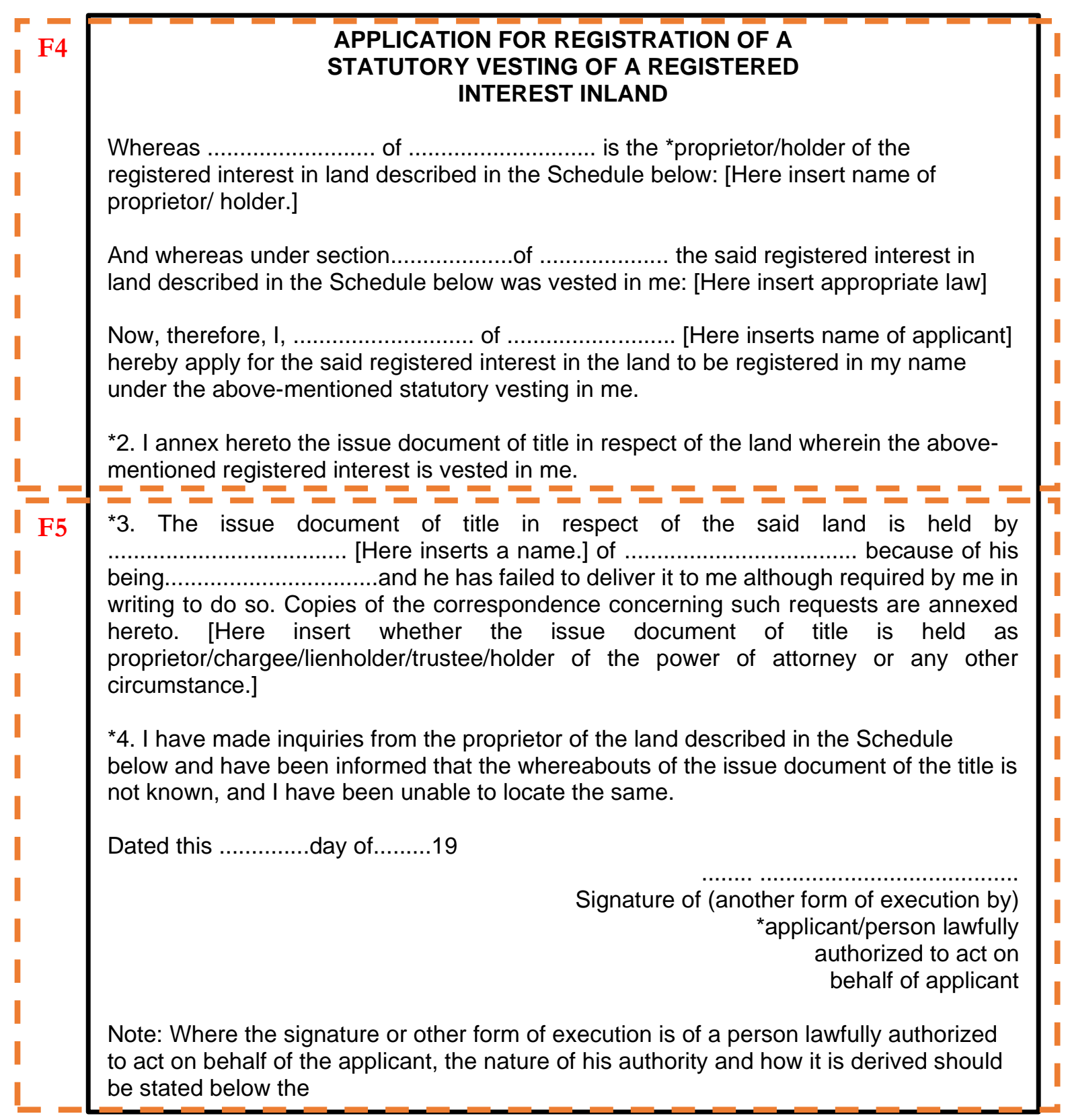

Figure 6 Waqf New Form (WNF, page 2)

Source: DLM, SIRC and Experts, (2019) 


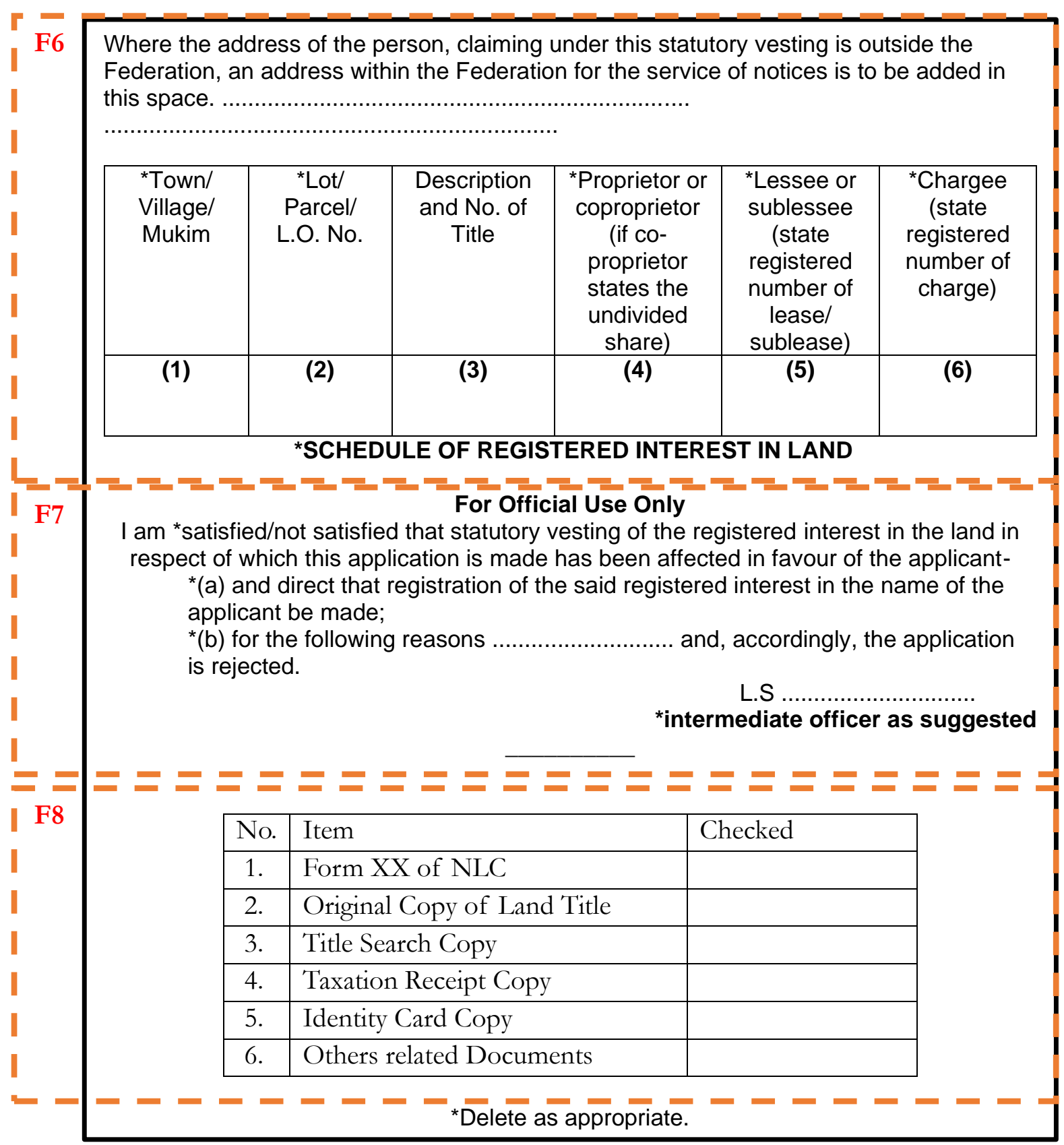

Figure 7 Waqf New Form ( $W \mathrm{NF}$, page 3)

Source: DLM, SIRC and Experts, (2019)

Figures 5, Figure 6 and Figure 7 shows the $W \mathrm{NF}$ as suggested to be enacted under the NLC. The details of the forms are summarised as below:

i. $\quad \mathrm{F} 1, \mathrm{~F} 4$, and F5, shows the details of donor (waqif)

ii. $\quad$ F2 shows the declaration of donor (sighab), and the purpose of property or beneficiaries (mawquf alaibi).

iii. $\quad$ F6- shows the details property (mawquf)

iv. F3, F5, and F7 shows the details manager (nazir) on Statutory Vesting with Qadi/Land Administrator's approval.

v. F8 shows the checklist of documents that the donor must attach to prove that the land is free from encumbrances 
With the approval of this form, the registration of the waqf land shall be binding and valid as the compliance of valid waqf elements according to Muslim jurists (Ghazali \& Raji, 2019; Hamid \& Tahir, 2018).

Overall, most of the respondents suggested that the WNF be enforced under the NLC because it can be referred to by every party involved. However, all the respondents also suggested that every waqif needs to clear the land encumbrances before creating waqf at SIRC, as defined in Section 340 of the NLC. Encumbrances can render the waqf declaration indefeasible, which includes:
a) Equity, Caveat (Part Ninetieth, Chapter 1, National Land Code 1965), and restrictions interest (mortgage/lease)
b) Taxation
c) Sole proprietorships
d) Inheritance right (Akta Pusaka Kecil 1955)

This declaration is parallel to Islamic Law, where subject property (mawquf) shall be free to be transferred. In Shafie School, the waqif must not be under any interdiction from either the property or himself from any debt; otherwise, the waqf shall be set aside, but the remaining property will be waqf (Ghazali \&Sipan, 2019, Mohd, 1982). The Hanafi School has a similar opinion; the waqif must have a composite capacity on waqif property (Husain, 2014). Otherwise, waqf is suspended if the waqf were made before the property was possessed until the waqif pays and possesses the property, but if he dies before it, the waqf is void (bati) (Baillie, 1965; Mohd, 1982). If the property is subject to a lease, the waqf shall revert to the purpose for which it has been dedicated after the expiration of the lease term. Similarly, if the pledger dies, the waqf is obligatory until it shall be redeemed (Baillie, 1965; Mohd, 1982).

\subsection{CONCLUSION}

In conclusion, the waqf property is essential for the benefit of ummah. However, to make it valid and binding requires many procedures and forms. Therefore, this research has highlighted the issues in waqf land registration procedures in the Malaysian legal system. The procedures consist of several steps and forms. Thus, this paper proposes a $W \mathrm{NF}$ for the waqif in all states that should be completed to register the waqf land. The form shall make the waqf declaration valid and binding. It is recommended that before the properties are declared as waqf, the land must be free from any encumbrances and the statutory vesting method should be used to register the name of SIRC at the Land Office. This research has limitations to access National Land Council experts. As National Land Council is authority bodies empowered to amend and review NLC, 1965. Thus, the research proposed framework shall be taken further to the National Land Council in order to study the enforcement of $W \mathrm{NF}$ in NLC, 1965. Hopefully, this $W \mathrm{NF}$ will secure the waqf properties in the future and eliminate the risk of waqf land being lost.

\section{Acknowledgement}

This research was supported by Skim Geran Penyelidikan Fundamental (Frgs) Fasa 1/2019: Universiti Teknologi Malaysia (UTM). We thank our colleagues from Universiti Teknologi Malaysia as the supporting institution that provided insight and expertise that greatly assisted the research 


\section{List of Reference}

Abdullah, M. (2020). Classical waqf, juristic analogy and framework of awqāf doctrines. ISR A International Journal of Islamic Finance, 12(2), 281-296. doi:10.1108/IJIF-07-2019-0102

Abu Talib, N. Y., Abdul Latiff, R., \& Aman, A. (2020). An institutional perspective for research in waqf accounting and reporting: A case study of Terengganu State Islamic Religious Council in Malaysia. Journal of Islamic Accounting and Business Research, 11(2), 400-427. doi:10.1108/JIABR-112016-0132

Akhtar, Z. (2013). Charitable trusts and waqfs: Their parallels, registration process, and tax reliefs in the United Kingdom. Statute Law Review, 34(3), 281-295. doi:10.1093/slr/hms045

Artha, E. U., Medias, F., \& Pambuko, Z. B. (2020). Evaluation of wakafMu fundraising platform using HOT-FIT method. Paper presented at the Journal of Physics: Conference Series, 1517(1) doi:10.1088/1742-6596/1517/1/012095 Retrieved from www.scopus.com

Asni, F., Mahamud, M. A., \& Sulong, J. (2020). Socio-economics and management of Muslim cemetery waqf using istibdal and GIS method in Penang State. Journal of Islamic Accounting and Business Research, 11(7), 1343-1362. doi:10.1108/JIABR-01-2019-0026

Author, (2019), Research in Phd Land Administration and Development Research, Universiti Teknologi Malaysia, 81310 Skudai, Johor.

Baillie, N. (1965). Digest of Moobummudan Law on the Subjects to Which It Is Usually Applied by British Courts of Justice. India: Smith, Elder \& Co, London.

Bazzi, S., Koehler-Derrick, G., \& Marx, B. (2020). The institutional foundations of religious politics: Evidence from Indonesia. Quarterly Journal of Economics, 135(2), 845-911. doi:10.1093/qje/qjz038

Crossman, A. (2017, June 3). An overview of chaos theory in sociology. Retrieved from: https://www.thoughtco.com/chaos-theory-3026621 Retrieved on 03/06/2018

DLM, SIRC and Experts, (2019), Interview at Department Land and Mines, State Islamic Religious Council, Academia and Lawyers.

Ghazali N.A, Raji, F., \& Mohammad, M.T.S.H. (2019). Issues on waqf land registration process in Malaysia and improvement proposals. UMRAN-International Journal of Islamic and Civilisational Studies, 6(3), $57-$ 71. doi:10.11113/umran2019.6n3.354

Ghazali, N.A., Sipan, I., Abas, F.N., Raji, F., \& Mohammad, M.T.S.H. (2019), Concept of valid contract declaration of waqf property in Islamic law. Journal of Fatwa Management and Research, 16(2), 224-252.

Ghazali, N.A., Sipan, I., Haji Mohammad, M.T.S. and Ab Aziz, M.A. (2021), "New framework for the management of waqf land registration system in Malaysia", International Journal of Islamic and Middle Eastern Finance and Management, 14(3), 625-640. https://doi.org/10.1108/IMEFM-04- 2019-0172,

Hanstad, T. (1998). Designing Land Registration Systems for Developing Countries: American University International Law Review, 13(3), 647-703.Husain, A. (2014). Muslim Personal Law. An Exposition. India, All India Personal Law Board. Camp Office. Retrieved from: http://muslimcanada.org/ muspersonallaw. html\#about Retrieved on 03/06/2018

Hamid, A. M. I., and Tahir, M. S. M. (2014). Waqf Property: Concept, Management, Development, and Financing. Skudai: UTM Press Publisher.

Hariyanto, E., Taufiq, M., Abidin, Z., Ulum, M., \& Maimun. (2020). Effectiveness of the economic system to zakat and waqf for empowerment of the ummah in Indonesia. International Journal of Advanced Science and Technology, 29(6), 1910-1916. Retrieved from www.scopus.com Retrieved on 03/06/2018 
Hossain, B. (2019). Islamic microfinance and rehabilitation model for the slum and floating population by waqf funds, the case of Bangladesh: A proposal for Muslim countries. Journal of King Abdulaziz University, Islamic Economics, 32(2), 139-160. doi:10.4197/Islec.32-2.11

Husain, A. (2014) Muslim Personal Law. An Exposition. India, All India Personal Law Board, Camp Office. Retrieved from: http://muslimcanada.org/muspersonallaw.html\#about Retrieved on 03/06/2018

Iman, N., Santoso, A., \& Kurniawan, E. (2020). Online based waqf management system in Indonesia: A new model in management of waqf administration. International Journal of Innovation, Creativity and Change, 10(11), 164-180. Retrieved from www.scopus.com Retrieved on 03/06/2018

Ismail, C. Z., Salim, N. J., \& Hanafiah, N. J. A. (2015). Administration and management of waqf land in Malaysia: Issues and solutions. Mediterranean Journal of Social Sciences, 6(4S2), 613-620. doi:10.5901/mjss. 2015.v6n4s2p613

Kader, S.A., Zubaidah, S., Dahlan, M., Hilal, N. (2009). Current legal issues concerning waqf in Malaysia.In: Waqf Laws \& Management: Reality and Prospects, International Conference. Cultural Activity Centre (CAC), International Islamic University Malaysia, Gombak Campus.

Khan, A., Mohd. Shafiai, M.H., Shaique, M. and Khan, S. (2020). Demographic determinants of charity donors and its implication for cash waqf institutions in Malaysia. Journal of Islamic Marketing, 13(2), 177-193. https://doi-org.ezproxy.utm.my/10.1108/JIMA-10-2019-0211

Komalasari, R. (2020). The waqf cemetery information system. Paper presented at the IOP Conference Series: Materials Science and Engineering, 879(1) doi:10.1088/1757-899X/879/1/012035 Retrieved from www.scopus.com. Retrieved on 03/06/2018

Kumar, R. (2019). Research Methodology: A Step-by-Step Guide for Beginners. London: SAGE Publications.

Mohammad, M.T.S.H. (2013). A proposal for a new comprehensive Waqf law in Malaysia, Retrieved from http://waqfacademy.org/wp-content/uploads/2013/03/Mohammad-Tahir-Sabit-Haji-

Mohammad.-Date.-Proposal-for-new-comprehensive-waqf-law-in Malaysia.pdf Retrieved on $03 / 06 / 2018$

Mohammad, M.T.S.H. (2006). Obstacles of the current concept of waqf to the development of waqf properties and the recommended alternative. Malaysian Journal of Real Estate, 1(1), 27-38.

Mohamood, S.M. (2005). International Conference on Harmonisation of Shari'ah and Civil Law 2, in Toward a Methodology of Harmonisation, H.M.H.L.C. Ahmad Ibrahim Kuliyyah of Laws, Editor, Jabatan Kehakiman Sharia Malaysia: Pan Pacific Hotel, Kuala Lumpur. 194

Mohd, Z.H.O. (1982). Islamic Law with Special Reference to the Institution of waqf. Kuala Lumpur, Prime Minister's Department Religious Affairs Division (Islamic Center). 1-9

National Land Code, 1965 (NLC), 'Act No. 56, Circular No 357/2020', Revised 2020, Kuala Lumpur; Bar Council Malaysia

Osman, A. Z., \& Agyemang, G. (2020). Privileging downward accountability in waqf management. Journal of Islamic Accounting and Business Research, 11(3), 533-554. doi:10.1108/JIABR-05-2017-0064

Osman, R. B., Ramli, N. A. B., \& Mohd Nor, M. Z. (2018). Waqfland administration and registration: Legal analysis. The Journal of Social Sciences Research. 1194-1201. 10.32861/jssr.spi6.1194.1201.

Pacific, U.O.T.S. (2014). Principles relating to the interpretation of statutes and constitutions. Port Vila, Vanuatu: PacLII. Retrieved from: http://www.vanuatu.usp.ac.fj/courses/LA304_Legal_Drafting/LA304_Unit\%203.html Retrieved on $03 / 06 / 2018$ 
Rani, M.A.M. \& Ghani, S.A. (2012). Implikasi Perundangan Terhadap Pendaftaran Tanah Wakaf di Malaysia: Satu Kajian Dari Aspek Akta Pengambilan Tanah 1960. Isu-isu Semasa Mengenai Waqaf, Pusat Penerbitan Universiti UiTM. Retrieved from: http://www.scribd.com/doc/81330622/Implikasi-Pendaftaran-Tanah-Wakaf Retrieved on $03 / 06 / 2018$

Razak, S. H. A. (2020). Zakat and waqf as instrument of Islamic wealth in poverty alleviation and redistribution: Case of Malaysia. International Journal of Sociology and Social Policy, 40(3-4), 249-266. doi:10.1108/IJSSP-11-2018-0208

Shabbir. M. S. (2018). Classification and prioritisation of waqf lands: A Selangor case. International Journal of Islamic and Middle Eastern Finance and Management, 11(1), 40-58. https://doi.org/10.1108/IMEFM-022017-0038

Sukmana, R. (2020). Critical assessment of Islamic endowment funds (waqf) literature: Lesson for government and future directions. Heliyon, 6(10), 10. doi: 10.1016/j.heliyon. 2020.e05074

Tajudin, M., Omar, R., Smedlund, A., \& Aziz, R. P. (2020). Financing with heart and intelligence: Augmenting intimacy and sustainability through Islamic fintech. International Journal of Advanced Science and Technology, 29(9 Special Issue), 1638-1664. Retrieved from www.scopus.com Retrieved on $03 / 06 / 2018$

Tumirin, T., Syaiful, S., Aufa, M., Mujaddid, A., Sholichah, M., \& Sukaris, S. (2020). Reconstruction of asset accountabilities definition and waqf asset. International Journal of Scientific and Technology Research, 9(3), 4925-4929. Retrieved from www.scopus.com. Retrieved on 03/06/2018

Zain, N. S., \& Sori, Z. M. (2020). An exploratory study on musharakah SRI sukuk for the development of waqf properties/ assets in Malaysia. Qualitative Research in Financial Markets, 12(3), 301-314. doi:10.1108/QRFM-09-2018-0099

Zauro, N. A., Saad, R. A. J., Ahmi, A., \& Mohd Hussin, M. Y. (2020). Integration of waqf towards enhancing financial inclusion and socio-economic justice in Nigeria. International Journal of Etbics and Systems, 36(4), 491-505. doi:10.1108/IJOES-04-2020-0054 